\title{
Mutants of Rhizobium tropici strain CIAT899 that do not induce chlorosis in plants
}

\author{
Kevin P. O'Connell, ${ }^{1,2}+$ Sandra J. Raffel, ${ }^{2}$ Barry J. Saville, ${ }^{2} \neq$ \\ and Jo Handelsman ${ }^{2}$ \\ Author for correspondence: Jo Handelsman. Tel: +1608263 8783. Fax: +16082628643. \\ e-mail: joh@plantpath.wisc.edu
}

Department of

Bacteriology ${ }^{1}$ and

Department of Plant

Pathology2, University of

Wisconsin-Madison, 1630

Linden Drive, Madison, WI

53706, USA

\begin{abstract}
Type B strains of Rhizobium tropici induce severe foliar chlorosis when applied at planting to seeds of symbiotic host and non-host dicotyledonous plants. A Tn5-induced mutant, designated CT4812, of R. tropici strain CIAT899 that was unable to induce chlorosis was isolated. Cloning and sequencing of the DNA flanking the transposon in CT4812 revealed that the Tn5 insertion is located in a gene similar to gInD, which encodes uridylyltransferase/uridylyl-removing enzyme in enteric bacteria. Two marker-exchange mutants with insertions in gInD also failed to induce chlorosis in bean (Phaseolus vulgaris) plants. The $\mathbf{5}^{\prime}$ most insertion in gInD (in mutant strain ME330) abolished the ability of $R$. tropici to utilize nitrate as a sole carbon source, whereas a mutation in gInD further downstream (in mutant strain ME245) did not have an obvious effect on nitrate utilization. A gene similar to the Salmonella typhimurium virulence gene mviN overlaps the $3^{\prime}$ end of the R. tropici ginD homologue. A mutation in muiN had no effect on the ability of CIAT899 to induce chlorosis in bean plants. Therefore the gInD homologue, but not mviN, appears to be required for induction of chlorosis in plants by $R$. tropici strain CIAT899. A high nitrogen : carbon ratio in the rhizosphere of bean plants also prevented $R$. tropici from inducing chlorosis in bean plants. Mutations in either the gInD homologue or mviN had no significant effect on root nodule formation or acetylene reduction activity. A mutation in mviN eliminated motility in $R$. tropici. The sequence data, the inability of the $g I n D$ mutant to utilize nitrate, and the role of the $R$. tropici ginD gene in chlorosis induction in plants, a process that is nitrogen regulated, suggest that $g \ln D$ plays a role in nitrogen sensing in $R$. tropici as its homologues do in other organisms.
\end{abstract}

Keywords: uridylyltransferase, $g \ln D, m v i N$, nitrogen regulon, chlorosis

\section{INTRODUCTION}

Rhizobium tropici induces the formation of nitrogenfixing nodules on the roots of plants belonging to several genera of tropical legumes, including Phaseolus, Leucaena and Macroptilium (Martinez-Romero et al.,

\footnotetext{
†Present address: Department of Pharmacology and Experimental Therapeutics, University of Maryland School of Medicine, $655 \mathrm{~W}$. Baltimore, MD 21209, USA. e-mail : kocon001@umaryland.edu.

¥Present address: Biology Group, Erindale College, University of Toronto, Mississauga, Ontario, L5L 1 C6 Canada.

Abbreviations: GUS, $\beta$-glucuronidase; X-gluc, 5-bromo-4-chloro-3-indolyl $\beta$-D-glucuronide.

The GenBank accession number for the sequence reported in this paper is U47030.
}

1991). Strains of $R$. tropici have been divided into two groups, A and B, based on multilocus enzyme electrophoresis, DNA-DNA hybridization, 16S rRNA gene sequences, plasmid profiles and an analysis of phenotypes (Geniaux et al., 1995; Martinez-Romero et al., 1991). CIAT899 (the type strain of $R$. tropici) can form colonies on acidic solid medium ( $\mathrm{pH} 4 \cdot 5)$, tolerates 50 p.p.m. $\mathrm{Mn}$ and 6 p.p.m. $\mathrm{Al}$ at $\mathrm{pH} 4 \cdot 7$, and can nodulate Phaseolus vulgaris (common bean) in acidic soil (as low as pH 3.8) (Graham et al., 1982). CIAT899 is therefore a desirable inoculant strain for use in tropical soils, which are often acidic (Graham et al., 1982; Martinez-Romero et al., 1991). We reported previously that CIAT899 and other type B strains of $R$. tropici induce chlorosis (yellowing) in the leaves of $P$. vulgaris, whereas type A strains of $R$. tropici do not (O'Connell et 
Table 1. Strains and plasmids used in this study

\begin{tabular}{|c|c|c|}
\hline Strain & Genotype or phenotype* & Source or reference \\
\hline \multicolumn{3}{|c|}{ Rhizobium tropici } \\
\hline CIAT899 & $\mathrm{Clr}^{+} \mathrm{Sp}^{\mathrm{r}} ;$ wild-type & Martinez-Romero et al. (1991) \\
\hline СТ9005 & $\begin{array}{l}\mathrm{Clr}^{+} \mathrm{Km}^{\mathrm{r}} \mathrm{Sp}^{\mathrm{r}} \mathrm{EPS}^{-} ; \text {CIAT899 } \\
\text { derivative }\end{array}$ & O'Connell et al. (1990) \\
\hline CT8014 & $\mathrm{Clr}^{+} \mathrm{Sp}^{\mathrm{r}} \mathrm{EPS}^{-} ;$CIAT899 derivative & O'Connell et al. (1990) \\
\hline CT 8032 & $\mathrm{Clr}^{+} \mathrm{Sp}^{\mathrm{r}}$ EPS $^{-}$; CIAT899 derivative & O'Connell et al. (1990) \\
\hline CT4812 & $\begin{array}{l}\mathrm{Clr}^{-} \mathrm{Sp}^{\mathrm{r}} \mathrm{Km}^{\mathrm{r}} ; \mathrm{CT} 8014 \text { derivative, } \\
g \ln D:: \operatorname{Tn} 5\end{array}$ & This study \\
\hline ME245 & CIAT899 $\ln D:: \operatorname{Tn} 5$ & This study \\
\hline ME330 & CIAT899 $g \ln D::$ Tn3-HoKmGus & This study \\
\hline ME370 & CIAT899 mviN::Tn3-HoKmGus & This study \\
\hline \multicolumn{3}{|l|}{$\begin{array}{l}\text { Agrobacterium } \\
\text { tumefaciens }\end{array}$} \\
\hline GMI9023 & C58 derivative cured of pTiC58 & Rosenberg \& Huguet (1984) \\
\hline \multicolumn{3}{|l|}{ Escherichia coli } \\
\hline $\mathrm{DH} 5 \alpha$ & $\begin{array}{l}\text { supE44 hsdR17 recA1 thi-1 } \\
\text { AlacU169( } \phi 80 \text { lacZ } \Delta M 15) \text { endA1 } \\
\text { gyrA96 relA1 }\end{array}$ & Hanahan (1983) \\
\hline $\mathrm{C} 2110$ & $\begin{array}{l}\text { Nal }^{\mathrm{r}} \text { polA1 his rha; host for Tn3- } \\
\text { HoKmGus-mutagenized plasmids }\end{array}$ & Kahn \& Helinski (1978) \\
\hline \multicolumn{3}{|l|}{ Plasmids } \\
\hline pLAFR3 & $\begin{array}{l}\mathrm{Tc}^{\mathrm{r}} ; \mathrm{pRK} 2 \text {-derived cosmid cloning } \\
\text { vector containing pUC8 polylinker }\end{array}$ & Keen et al. (1988) \\
\hline pRK2013 & $\begin{array}{l}\mathrm{Km}^{\mathrm{r}} \mathrm{Tra}^{+} ; m o b ; \text { 'helper' plasmid for } \\
\text { triparental matings }\end{array}$ & Figurski \& Helinski (1979) \\
\hline pSUP202 & $\begin{array}{l}\mathrm{Ap}^{r} \mathrm{Cm}^{r} \mathrm{Tc}^{r} ; \mathrm{pBR} 325 \text { derivative } \\
\text { containing pRK2 mob site }\end{array}$ & Simon et al. $\langle 1983\rangle$ \\
\hline pGS9 & p15A replicon; Tn5-carrying vector & Selveraj \& Iyer (1983) \\
\hline pJQ200 & Gene replacement vector & Quandt \& Hynes (1993) \\
\hline pGEM-3Zf $(+)$ & $A_{m p}{ }^{r} l a c Z \alpha$ & Promega \\
\hline pSShe & Derived from pACYC184; $\operatorname{tn} p A \mathrm{Cm}^{\mathrm{r}}$ & Stachel et al. (1985) \\
\hline pHoKmGus & $\begin{array}{l}\text { pHoHo1 derivative; carries } \operatorname{Tn} 3 \\
\text { derivative containing promoterless } \beta \text { - } \\
\text { glucuronidase gene; } \mathrm{Km}^{\mathrm{r}}\end{array}$ & Bonas et al. (1989) \\
\hline pJM528 & $\begin{array}{l}\mathrm{Tc}^{\mathrm{r}} ; \text { pLA2917 containing cloned } R \text {. } \\
\text { tropici DNA }\end{array}$ & Milner et al. (1992); this study \\
\hline pJM529 & $\begin{array}{l}\mathrm{Tc}^{\mathrm{r}} ; \text { pLA } 2917 \text { containing cloned } R . \\
\text { tropici DNA }\end{array}$ & Milner et al. (1992); this study \\
\hline pKO4812 & $\begin{array}{l}\mathrm{Tc}^{\mathrm{r}} \mathrm{Km}^{\mathrm{r}} ; \text { EcoRI fragment of CT4812 } \\
\text { DNA containing Tn5 cloned into } \\
\text { pSUP202 }\end{array}$ & This study \\
\hline pKO1 & $\begin{array}{l}\mathrm{Tc}^{\mathrm{r}} \text {; pLAFR } 3 \text { containing } 10 \mathrm{~kb} \text { HindIII } \\
\text { fragment subcloned from pJM } 528\end{array}$ & This study \\
\hline pKO7.3 & $\begin{array}{l}7 \cdot 3 \mathrm{~kb} \text { Bam HI fragment of pKO1 } \\
\text { cloned into pLAFR } 3\end{array}$ & This study \\
\hline pKO2.85 & $\begin{array}{l}2.85 \mathrm{~kb} \text { HindIII-Bam HI fragment of } \\
\text { pKO1 cloned into pLAFR } 3\end{array}$ & This study \\
\hline pKO316 & pKO1; glnD::Tn3-HoKmGus & This study \\
\hline pKO330 & pKO1; glnD::Tn3-HoKmGus & This study \\
\hline pKO370 & pKO1; mviN::Tn3-HoKmGus & This study \\
\hline $\mathrm{pKO} 345$ & pKO1; $g \ln D:: \operatorname{Tn} 3-\mathrm{HoKmGus}$ & This study \\
\hline pKO302 & pKO1; ORF3:: Tn3-HoKmGus & This study \\
\hline pGCHL1.8-2 & $\begin{array}{l}1.8 \mathrm{~kb} \text { EcoRI fragment of pKO1 cloned } \\
\text { into } \mathrm{pGEM}-3 \mathrm{Zf}(+)\end{array}$ & This study \\
\hline pGCHL3.0 & $\begin{array}{l}3.0 \mathrm{~kb} \text { Pst I fragment of pKO1 cloned } \\
\text { into pGEM3-Zf }(+)\end{array}$ & This study \\
\hline
\end{tabular}

${ }^{*} \mathrm{Clr}^{+}$, induces chlorosis; $\mathrm{Clr}^{-}$, does not induce chlorosis; $\mathrm{EPS}^{-}$, deficient in exopolysaccharide production. 
al., 1990; O'Connell \& Handelsman, 1993). CIAT899 also induces chlorosis in other host legumes and nonhost dicotyledonous plants ( $\mathrm{O}^{\prime}$ Connell \& Handelsman, 1993). The induction of chlorosis depends on the availability of a carbon source in the rhizosphere, the presence of which does not affect bacterial growth (O'Connell \& Handelsman, 1993). Symptoms that accompany foliar chlorosis often include stunting and loss of apical dominance (O'Connell \& Handelsman, 1993); superficially, the chlorosis induced by CIAT899 resembles iron deficiency in Phaseolus beans (Schwartz, 1991).

The data we presented previously (O'Connell et al., 1990; O'Connell \& Handelsman, 1993) are consistent with the hypothesis that $R$. tropici type B strains produce a chlorosis-inducing factor or toxin; however, we did not detect chlorosis-inducing activity in culture filtrates in several experiments (K. P. O'Connell \& J. Handelsman, unpublished data). We therefore used a genetic approach to understand the mechanism of chlorosis induction in plants by $R$. tropici strain CIAT899. Here we report that a transposon insertion in a homologue of $g \ln D$, which encodes a nitrogen sensor in enteric and other bacteria (Kennedy et al., 1994; Merrick \& Edwards, 1995), eliminates the ability of CIAT899 to induce chlorosis in plants. We also demonstrate that a high carbon: nitrogen ratio in the rhizosphere is required for the development of symptoms in plants inoculated with chlorosis-inducing $R$. tropici. This finding suggests a role for the $g \ln D$ homologue in the regulation of chlorosis-inducing ability in response to environmental nitrogen levels.

\section{METHODS}

Strains, plasmids and bacterial growth conditions. The bacterial strains and plasmids used in this study are listed in Table 1. All bacteria listed except Escherichia coli were grown to saturation (3-4d) in yeast extract/mannitol (YM) broth (Wacek \& Brill, 1976) at $28^{\circ} \mathrm{C}$ on a rotary shaker. Cultures were maintained on YM, tryptone/yeast extract (TY) (Beringer, 1974) or minimal (BSM) medium (Bergersen, 1961) containing $15 \mathrm{~g}$ agar $\mathrm{l}^{-1}$, or frozen to $-80^{\circ} \mathrm{C}$ in YM or Luria broth (LB) (Sambrook et al., 1989) containing 10\% dimethyl sulfoxide. Cultures of $E$. coli were grown in $\mathrm{LB}$ at $37^{\circ} \mathrm{C}$ and maintained on solid LB containing $15 \mathrm{~g}$ agar $\mathrm{l}^{-1}$. Antibiotics (Sigma) for Rbizobium were added to solid media at the following concentrations: spectinomycin (Sp) $200 \mu \mathrm{g} \mathrm{ml}^{-1}$, kanamycin $(\mathrm{Km}) 200 \mu \mathrm{g} \mathrm{ml}^{-1}$, streptomycin $(\mathrm{Sm}) 200 \mu \mathrm{g} \mathrm{ml}^{-1}$, tetracycline $\left(\mathrm{Tc}_{\mathrm{c}}\right) 10 \mu \mathrm{g} \mathrm{ml} \mathrm{g}^{-1}$, gentamicin $(\mathrm{Gm}) 15 \mu \mathrm{g} \mathrm{ml} \mathrm{m}^{-1}$. Antibiotics for E. coli were added to solid media at the following concentrations: ampicillin (Ap) $100 \mu \mathrm{g} \mathrm{ml}^{-1}$, chloramphenicol $(\mathrm{Cm}) 10 \mu \mathrm{g} \mathrm{ml}^{-1}$, kanamycin $50 \mu \mathrm{g} \mathrm{ml}^{-1}$, nalidixic acid (Nal) $10 \mu \mathrm{g} \mathrm{ml}^{-1}$, tetracycline $10 \mu \mathrm{g} \mathrm{ml}^{-1}$.

Plant growth conditions. Bean seeds were surface-disinfected and planted in large test tubes containing sterile sand and vermiculite as described previously (Araujo et al., 1986; Beattie et al., 1989). Seeds of common bean (Phaseolus vulgaris L.) cultivar WBR22-34 (Bliss et al., 1989) were obtained from K. Kmiecik, Department of Horticulture, University of Wisconsin-Madison, and from J. C. Rosas, Escuela Agricola
Panamericana, Zamorano, Honduras. Seeds of bean cultivar Puebla 152 were provided by K. Kmiecik. Plants were watered with sterile distilled water and maintained in growth chambers at $24^{\circ} \mathrm{C}$ with a $12 \mathrm{~h}$ photoperiod and a light intensity of $150 \mu \mathrm{E} \mathrm{m}^{-2} \mathrm{~s}^{-1}$.

Bacterial mutagenesis and screening for loss of the ability to induce chlorosis (yellowing) in bean plants. Chlorosisinducing $R$. tropici strains CT8014 and CT8032 (derived from CIAT899; O'Connell et al., 1990) were mutagenized using Tn5-carrying plasmid pGS9. $\mathrm{Km}^{\mathrm{r}}$ isolates of CT8014 and CT8032 occurred at a frequency of $3 \times 10^{-6}$ per recipient. Mutagenized $\mathrm{Km}^{\mathrm{r}}$ isolates (a total of 1880) were screened individually for loss of the ability to induce foliar chlorosis in $P$. vulgaris. One bean seed was inoculated with $1 \mathrm{ml}$ of a saturated YM culture of a $\mathrm{Km}^{\mathrm{r}}$ isolate (approx. $10^{8}-10^{9}$ bacteria $\mathrm{ml}^{-1}$ ) at planting. Three to four weeks after planting and inoculation, the first trifoliate leaves were examined for the presence (and severity) or absence of chlorosis. The severity of chlorosis in bean leaves was rated as pictured previously (O'Connell et al., 1990), on a scale of 1 (green leaves, no chlorosis) to 5 (nearly white leaves, severe chlorosis). Approximately $10 \%$ of the $\mathrm{Km}^{\mathrm{r}}$ isolates failed to induce chlorosis in this first screen. Subsequent retesting confirmed that one mutant of strain CT8014, designated strain CT4812, was repeatably unable to induce chlorosis.

In later experiments, strains of R. tropici were grown in YM broth plus $\mathrm{Km}$ and resuspended at a concentration of approximately $10^{7}$ c.f.u. $\mathrm{ml}^{-1}$ in a sterile solution of $137 \mathrm{mM}$ $\left(25 \mathrm{~g}^{-1}\right)$ mannitol (Sigma), or in a solution of mannitol plus a nitrogen source, as described in Results, and then tested as described above. Chlorosis-inducing strains of $R$. tropici resuspended in $137 \mathrm{mM}$ mannitol produce more consistent and severe chlorosis than the same bacteria inoculated directly from YM broth cultures, presumably because the carbon source is more abundant (O'Connell \& Handelsman, 1993).

Isolation of cosmids that restore chlorosis-inducing ability to CT4812. A gene library of CIAT899 (Milner et al., 1992) was mobilized into CT4812 by triparental mating (Ditta et al., 1980) and screened for cosmids that restored chlorosisinducing ability to CT4812. Chlorosis can be induced by as few as $4 \times 10^{3}$ chlorosis-inducing bacteria in the presence of $9 \times 10^{8}$ non-inducers (K.P. O'Connell \& J. Handelsman, unpublished data). Batches of 50 cosmid-containing isolates were applied to two bean seeds at planting and the plants were examined after 3 weeks for the onset of chlorosis. Individuals in those batches that induced chlorosis were then screened separately to determine which clones contained CIAT899 DNA that restored the ability to induce chlorosis. Two cosmids with identical restriction patterns, pJM528 and pJM529, restored the ability of CT 4812 to induce chlorosis. A $10 \mathrm{~kb}$ HindIII fragment from pJM528 was subcloned into the vector pLAFR3, resulting in plasmid pKO1.

Plasmid mutagenesis. Plasmid pKO1 was mutagenized by the method of Bonas et al. (1989) using the transposon Tn3HoKmGus, which contains a promoterless uidA gene and creates transcriptional fusions when inserted downstream of active promoters. $\beta$-Glucuronidase (GUS) activity was measured by monitoring the cleavage of 4-methylumbelliferyl- $\beta$-Dglucuronide (Sigma) to 4-methylumbelliferone by the method of Jefferson (1987), using a Hoefer TK100 fluorometer (Hoefer Scientific Instruments). GUS activity in bacteria grown on solid media was observed by including 5-bromo-4-chloro-3indolyl $\beta$-D-glucuronide (X-gluc) (Clontech) at a concentration of $50 \mu \mathrm{g} \mathrm{ml}^{-1}$. 
Construction of marker-exchange mutants. The $\operatorname{Tn} 5$ insertion mutation and flanking DNA in CT4812 was cloned and recombined into the genome of CIAT899 by marker exchange. Fragments $(7-8 \mathrm{~kb})$ of EcoRI-digested genomic DNA from CT4812 were ligated into the unique EcoRI site of the suicide vector pSUP202 and transformed into E. coli strain DH5 $\alpha$. The resulting plasmid $\left(\mathrm{Km}^{\mathrm{r}}\right)$ was designated pKO4812. Plasmid pKO4812 was mobilized into CIAT899 from $E$. coli by triparental mating. $\mathrm{Sp}^{\mathrm{r}}$ and $\mathrm{Km}^{\mathrm{r}}$ transconjugants were then screened for the loss of $\mathrm{Tc}^{\mathrm{r}}$. The resulting mutant was designated ME245.

The Tn3-HoKmGus insertion was cloned from pKO370 and introduced into the genome of CIAT 899 by marker exchange. An $11 \mathrm{~kb} \mathrm{Nsi}$ fragment of pKO370 was cloned into the Pst I site of the vector pJQ200 (Quandt \& Hynes, 1993). The resulting plasmid was mobilized from $E$. coli strain $\mathrm{DH} 5 \alpha$ by triparental mating into $R$. tropici CIAT899, selecting for resistance to $\mathrm{Sp}, \mathrm{Km}$ and $\mathrm{Gm}$, resulting in single recombinations between the cloned DNA and the CIAT899 genome. Double recombinants were isolated by culturing the transconjugants in $\mathrm{YM}$ broth containing $\mathrm{Sp}$ and $\mathrm{Km}$, and screening for resistance to sucrose $(5 \%)$ and loss of $\mathrm{Gm}^{\mathrm{r}}$. The $\mathrm{Tn} 3-$ HoKmGus insertion in pKO330 was similarly cloned and introduced into the CIAT899 genome, resulting in strain ME330. Marker exchange in all mutants was verified by Southern blot analysis.

Molecular methods. DNA isolation, subcloning, restriction digests and agarose gel electrophoresis were performed by standard methods (Ausubel et al., 1987; Sambrook et al., 1989). Southern blot experiments were performed using the Genius labelling kit (Boehringer Mannheim) and Magnagraph membranes (Micron Separations) according to the manufacturers' instructions. Plasmids were prepared from E. coli strain DH $5 \alpha$ using either the Wizard Miniprep Kit (Promega) or Qiagen columns (Qiagen). DNA sequence was obtained using pKO1 and two subclones, pGCHL1.8-2 and pGCHL3.0, as template. Sequencing reactions were performed with PRISM Ready Reaction DyeDeoxy Terminator Cycle Sequencing kits (Applied Biosystems), according to the manufacturer's instructions. Sequencing reaction products were analysed on an Applied Biosystems model 373 sequencer at the University of Wisconsin Biotechnology Center (UWBC). Sequencing primers were obtained from the UWBC. Sequence data were assembled and analysed using the Genetics Computer Group (Devereux et al., 1984) and DNASTAR sequence analysis packages.

\section{RESULTS}

\section{Isolation of a $R$. tropici mutant that does not induce chlorosis in plants}

To understand the mechanism by which type B strains of $R$. tropici induce chlorosis in dicotyledonous plants, we sought to isolate and identify genes required for this activity. EPS-deficient strains CT8014 and CT8032 were mutagenized with transposon $\operatorname{Tn} 5$ and screened for mutants that did not induce chlorosis in $P$. vulgaris leaves. Strains CT8014 and CT8032 are deficient in exopolysaccharide (EPS) production, but induce nitrogen-fixing nodules and retain the ability to induce severe chlorosis in bean plants (O'Connell et al., 1990). At the time this work was initiated, it appeared that a deficiency in EPS synthesis was necessary for chlorosis induction. We observed later (O'Connell \& Handels-
Table 2. Chlorosis induced by Rhizobium tropici CIAT899 and marker-exchange mutants

\begin{tabular}{|lc|}
\hline Inoculum strain* $^{*}$ & Chlorosis rating $\dagger$ \\
\hline CIAT899 & $3 \cdot 7 \pm 0 \cdot 2^{a}$ \\
ME370 (mviN::Tn3-HoKmGus) & $3 \cdot 7 \pm 0 \cdot 2^{a}$ \\
ME330 (glnD::Tn3-HoKmGus) & $1 \cdot 0 \pm 0 \cdot 0^{b}$ \\
ME245 (glnD::Tn5) & $1 \cdot 0 \pm 0 \cdot 0^{b}$ \\
CT4812 (glnD::Tn5) & $1 \cdot 1 \pm 0 \cdot 1^{b}$ \\
Mannitol solution & $1 \cdot 1 \pm 0 \cdot 0^{b}$ \\
Water & $1 \cdot 0 \pm 0 \cdot 0^{b}$ \\
\hline
\end{tabular}

"Inoculum bacteria were suspended in a mannitol solution as described in Methods.

† Chlorotic plants were rated on a scale of 1 (no chlorosis) to 5 (nearly white leaves, severe or complete chlorosis). Each value represents the mean chlorosis rating of 10-35 Phaseolus plants $( \pm \mathrm{SE})$ from three combined experiments. Values followed by the same letter are not significantly different $(P<0.05)$ by Tukey's Studentized range test (HSD $=0.49$ ).

man, 1993) that wild-type strain CIAT899 induces severe chlorosis in dicotyledonous plants when inoculated onto seeds at planting in the presence of a carbon source. This is also the reason that EPS-deficient strain CT9005 was used in the rhizosphere nitrogen experiments described below.

The severity of chlorosis in bean leaves was rated on a scale of 1 (green leaves, no chlorosis) to 5 (nearly white leaves, severe chlorosis) (O'Connell et al., 1990). Out of 1880 mutants screened, one designated CT4812 lacked the ability to induce chlorosis. In an early experiment, CT4812 induced no chlorosis in bean plants (mean chlorosis rating of $1.0 \pm 0.0$ ), versus a mean chlorosis rating $3 \cdot 0 \pm 0.4$ for plants inoculated with CT8014 in a typical experiment ( $n=10$ plants, $P<0.05$ by Tukey's Studentized range test, $\mathrm{HSD}=1.92)$. Strains CT4812 and CT8014 are isogenic apart from the presence of the transposon in strain CT4812. We verified that the Tn5 insertion mutation in CT4812 was responsible for the loss of chlorosis-inducing ability by cloning the transposon and introducing it into CIAT899 by marker exchange. The resulting marker-exchange mutant, ME245, also lacked the ability to induce chlorosis in bean plants (Table 2).

A second, independent mutation was created by marker exchange in the $g \ln D$ locus of CIAT899, using the Tn3HoKmGus insert in pKO330 (Fig. 1) as described in Methods. The resulting mutant, ME330, also failed to induce chlorosis in plants (Table 2).

\section{Isolation of cosmids that restore chlorosis-inducing ability to CT4812}

A cosmid library of CIAT899 was screened in batches of 50 for cosmids that restored the chlorosis-inducing ability of CT4812. One transconjugant from each of two batches induced chlorosis. These isolates contained 


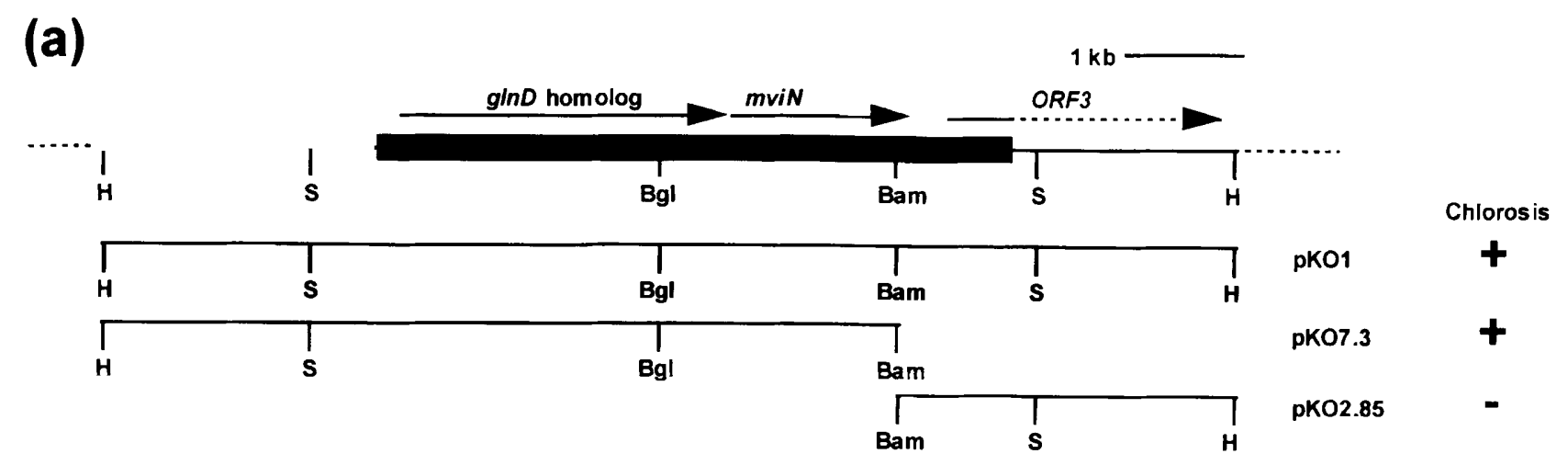

(b)

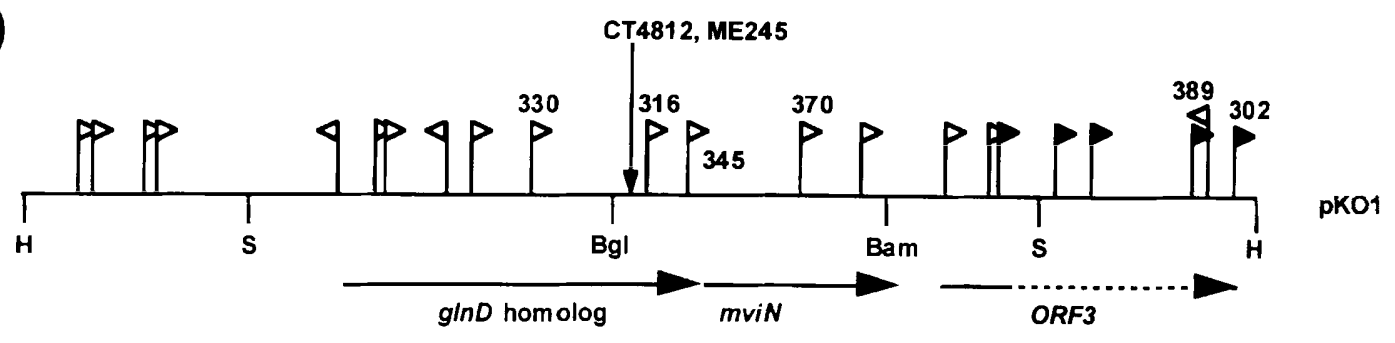

Fig. 1. (a) Physical map of pKO1 and subclones. A $10 \mathrm{~kb}$ Hindlll fragment of pJM528 DNA was subcloned into pLAFR3 to generate pKO1. The black bar indicates the region that has been sequenced. (b) Locations of Tn3-HoKmGus inserts in pKO1 as determined by restriction analysis. Numbers above the flags refer to the plasmids derived from pKO1 that contain insertions in the indicated positions. Insertions in pKO316, pKO370 and the Tn5 insertion in pKO4812 were precisely mapped by sequencing the flanking genomic DNA. The vertical arrow indicates the location of the Tn5 insert in the chromosomes of CT4812 and ME245. Solid flags indicate Tn3-HoKmGus insertions that resulted in blue colonies of CT4812 containing the corresponding plasmid on TY plates containing X-gluc; open flags indicate white colonies. Numbered transposons are referred to in the text. Open flags in the $5^{\prime}$ end of the downstream ORF may actually map between mviN and the downstream ORF. Abbreviations: H, HindlII; S, Sall; Bgl, BgllI; Bam, BamHI; +, restored chlorosisinducing ability to CT4812 when cloned into pLAFR3 and introduced by triparental mating; - , did not restore chlorosisinducing ability.

cosmids, pJM528 and pJM529, which had identical restriction patterns. Plants inoculated with CT4812(pJM528) were severely chlorotic (mean rating of $4 \cdot 0 \pm 0.5, n=10$ ). Cosmid pJM528 was chosen for subsequent analysis.

DNA hybridization analysis of CT4812 genomic DNA using labelled pJM528 as the probe revealed that the Tn5 mutation in CT4812 was located in a $10 \mathrm{~kb}$ HindIII fragment. A $10 \mathrm{~kb}$ HindIII fragment from pJM528 was subcloned in pLAFR 3 to produce plasmid pKO1, which also restored the ability of CT4812 to induce chlorosis (Fig. 1a). Further subcloning yielded plasmids pKO7.3, which restored chlorosis induction in strain CT4812, and $\mathrm{pKO} 2.85$, which did not restore chlorosis induction in CT4812 (Fig. 1a).

Cosmid pJM528 did not confer the ability to induce chlorosis in bean plants on wild-type strains of other bacterial species tested, including $R$. tropici type A strains (which we previously showed do not induce chlorosis; O'Connell \& Handelsman, 1993), Rhizobium etli, Agrobacterium tumefaciens, E. coli, Erwinia herbicola and Burkholderia cepacia (data not shown). Therefore, either pJM528 does not carry all the genetic determinants required for chlorosis induction, or all of the components are present on pJM528 but are not all expressed in the heterologous bacteria under the conditions tested.

We isolated total genomic DNA from three A. tumefaciens strains: GMI9023, GMI9023(pCIAT899a,b) (carrying both $R$. tropici megaplasmids; Brom et al., 1988) and GMI9023 (pCIAT899b). Genomic DNA from these three strains was probed with the $10 \mathrm{~kb}$ insert from pKO1. The $10 \mathrm{~kb}$ insert did not hybridize either to GMI9023 genomic DNA, or to DNA from GMI9023 carrying the R. tropici megaplasmids (K. P. O'Connell \& J. Handelsman, unpublished data). This result suggests that the $\mathrm{Tn} 5$ insertion in CT 4812 resided on the chromosome, since other plasmids were not detected in CIAT899 (Brom et al., 1988), the parent strain of CT4812.

\section{Strain CT4812 contains a mutation in a gene with sequence similarity to $g / n D$}

The Tn 5 and flanking DNA were cloned from mutant CT4812. Sequencing of the cloned DNA flanking the $\mathrm{Tn} 5$ insertion in CT4812 revealed that the mutation was 
located in an ORF that encodes a predicted polypeptide similar to GlnD, the uridylyltransferase/uridylyl-removing enzyme (UTase/UR protein) of the nitrogen regulatory cascade in enteric bacteria (van Heeswijk et al., 1993), and to $\mathrm{NfrX}$, a nitrogen-fixation regulatory protein of Azotobacter vinelandii (Contreras et al., 1991). The $g \ln D$ homologue in CIAT899 encodes a predicted polypeptide of 971 amino acids, with a molecular mass of $109149 \mathrm{Da}$ and an isoelectric point of 7.3. The predicted polypeptide is $32 \%$ identical and $56 \%$ similar to the GlnD protein of E. coli, and $34 \%$ identical and $56 \%$ similar to the regulatory protein $\mathrm{NfrX}$ of A. vinelandii (Fig. 2). All three proteins contain the conserved nucleotidyltransferase-superfamily motif characteristic of uridylyltransferases (Holm \& Sander, 1995). Unlike enteric bacteria containing mutant $g \ln D$ alleles (Bloom et al., 1978; Foor et al., 1978), CT4812 and ME245 did not display a requirement for glutamine and were able to use nitrate, histidine and arginine as sole nitrogen sources in modified BSM medium (data not shown). However, marker-exchange mutant ME330 was unable to utilize nitrate as a sole nitrogen source on solid minimal medium, and grew poorly on arginine as a nitrogen source. Because the mutation in ME330 is closer to the $5^{\prime}$ end of the $g \ln D \mathrm{ORF}$, it is possible that the insertions in strains CT4812 and ME245 allow the production of a truncated protein product sufficient to allow nitrate utilization, but not chlorosis induction. The insertion in $g \ln D$ in strains CT4812, ME245 and ME330 did not affect the ability to induce pink nodules on the roots of Phaseolus beans. Unlike $n f r X$ mutants of A. vinelandii, which lack nitrogenase activity, mutants CT4812, ME245 and ME330 all had acetylene-reduction activity comparable to the wild-type strain CIAT899 after root nodules developed (data not shown). Thus, while similar in primary structure to $\mathrm{NfrX}$ and GlnD, a complete GlnD protein in CIAT899 was not required for nitrogen fixation in the manner of NfrX. However, our data do suggest that $\mathrm{GlnD}$ is required for nitrogen utilization by CIAT899.

A note on genetic nomenclature: we refer to the CIAT899 gene interrupted in strains CT4812, ME245 and ME330 as a $g \ln D$ gene, based on the similarity of its sequence to the sequences of $g \ln D$ genes isolated from enteric bacteria and its likely involvement in the utilization of nitrate as a nitrogen source. We acknowledge that this designation is tentative, as we have not demonstrated that the product of this gene has UTase/UR activity. In the following section, we use the designation $m v i N$ for the R. tropici gene freely, because the biochemical function of mviN and similar genes is unknown and the association of this family of genes is based solely upon sequence similarity.

\section{An ORF overlapping $g \ln D$ is similar to the virulence gene mviN}

The last amino-acid-encoding codon and the stop codon of $g \ln D$ overlap the start codon of a second ORF that encodes a protein similar to MviN, a mouse virulence determinant in Salmonella typhimurium (Carsiotis et al., 1989). The mviN homologue of CIAT899 encodes a predicted polypeptide of 533 amino acids with a molecular mass of $57507 \mathrm{Da}$ and an isoelectric point of 9.8. The predicted protein is $34 \%$ identical and $60 \%$ similar to MviN of S. typhimurium. Just $3^{\prime}$ to the stop codon of $m v i N$ is a 19 -base inverted repeat that may serve as a transcriptional terminator. Genes similar to $m v i N$ also occur in several other bacteria (E. coli, GenBank accession number U00096; Haemophilus influenzae, GenBank accession number U32777; Chlamydia trachomatis, GenBank accession number U50732; Mycobacterium tuberculosis, GenBank accession number Z94121; Synechocystis sp. PCC6803, GenBank accession number D64001). Whilst CIAT899 is not known to be a mouse pathogen, we provisionally designate this $R$. tropicigene mviN until the biochemical function of this group of proteins is understood. Downstream of $m v i N$ we sequenced the $5^{\prime}$ end of a third ORF (ORF3) that encodes a predicted protein of unknown function, similar to a hypothetical protein in Shewanella putrefaciens (GenBank accession number L04283).

\section{A mutation in mviN has no effect on chlorosis induction in plants}

The overlap of the stop codon of $g \ln D$ and the start codon of mviN suggested that these two genes may be co-transcribed and that their translation may be coupled. It was therefore possible that the $\operatorname{Tn} 5$ insertion in CT4812 and ME245 could prevent the expression of $m v i \mathrm{~N}$ and that the lack of expression of $m v i \mathrm{~N}$ was responsible for the loss of ability to induce chlorosis in plants. To determine whether an insertion mutation in $m v i N$ prevents CIAT899 from inducing chlorosis in plants, we isolated several Tn3-HoKmGus insertions in the plasmid pKO1, some of which were located in $m v i \mathrm{~N}$ (Fig. 1b). We chose the insertion in pKO370 (Fig. 1b) to recombine into the chromosomal mviN in CIAT899 by marker exchange. The resulting mutant, ME370, induced chlorosis in bean plants indistinguishable from that induced by CIAT899 (Table 2). Therefore, unlike a mutation in $g \ln D$, a mutation in mviN did not prevent chlorosis induction by CIAT899 in bean plants, suggesting that the $g \ln D$ gene product, but not MviN, is required to induce chlorosis in plants. On Phaseolus beans, mutant strain ME370 induced pink nodules indistinguishable from those induced by wildtype bacteria and plants nodulated with strain ME370 had acetylene-reduction activity comparable to plants nodulated by wild-type strain CIAT899 (data not shown), suggesting that $\mathrm{MviN}$ is not required for nodulation or nitrogen fixation.

\section{A mutation in mviN eliminates motility in $R$. tropici}

mviN appears to be required for motility in R. tropici. In two independent experiments, strains CIAT899, CT4812, ME245 and ME370 were tested for motility by 


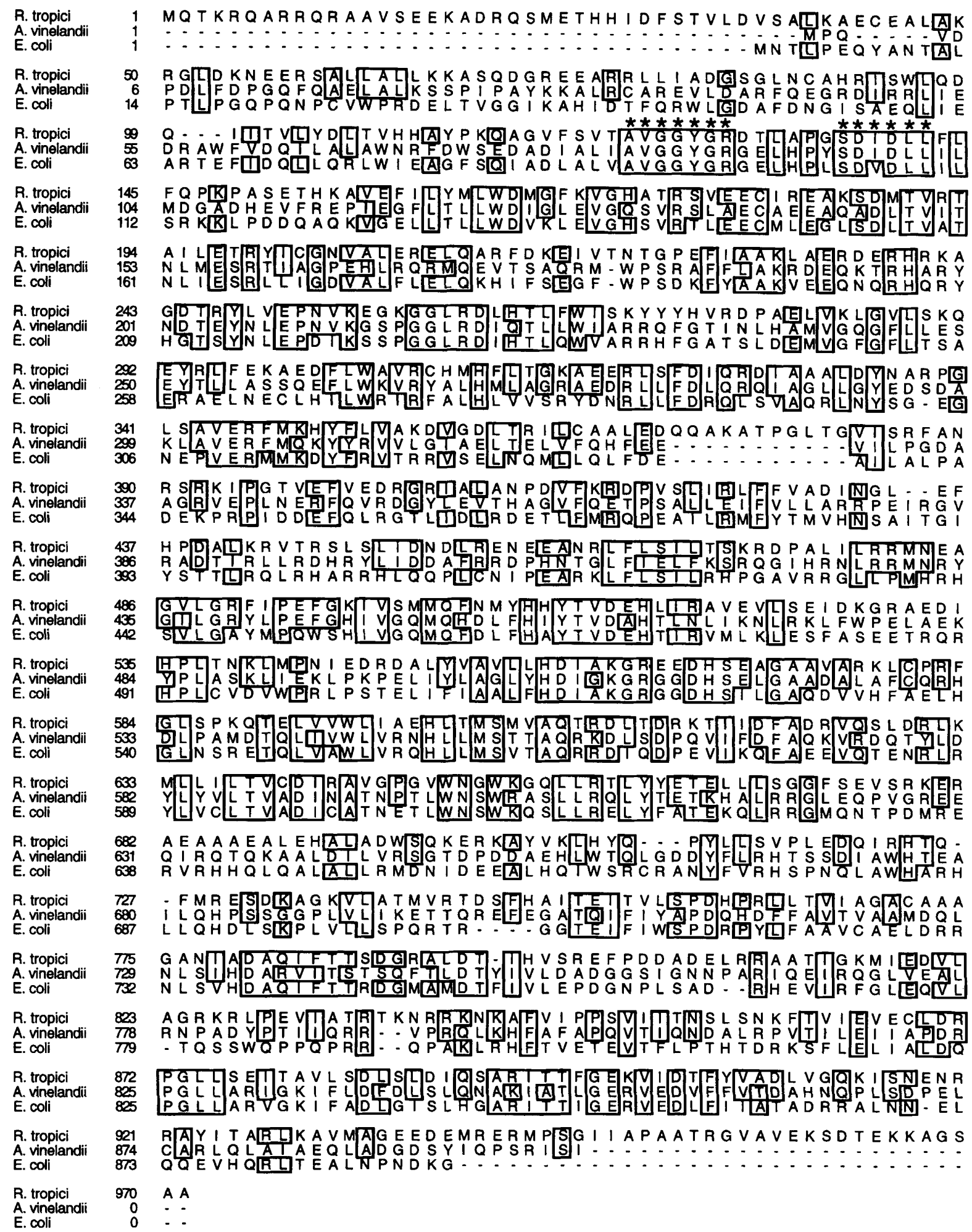

Fig. 2. Comparison of the peptide sequences of the GInD homologue from R. tropici, NfrX of $A$. vinelandii and the GInD protein of $E$. coli. Residues identical to the $R$. tropici predicted peptide are boxed. The residues that are conserved in the nucleotidyltransferase superfamily of proteins are indicated by asterisks above the residues. The GenBank accession number of the $R$. tropici sequence is $\cup 47030$.

stabbing cells of each strain into solid $0 \cdot 1 \times \mathrm{YM}$ with $0.3 \%$ agar. Strain ME370 (mviN::Tn3-HoKmGus) did not swarm away from the site of inoculation; all other strains displayed motility indistinguishable from the wild-type strain. The function of mviN in motility in $S$. typhimurium is unclear. Mutants of S. typhimurium 
deleted for $m v i \mathrm{~N}$ (then called $m v i S$ ) also had deletions in nearby motility genes (Carsiotis et al., 1989). To the best of our knowledge, there are no insertion, point, or deletion mutants of S. typhimurium that lack only a functional mviN gene.

\section{Expression of genes carried on plasmid pKO1}

While the mutational studies suggested that an intact $g \ln D$ gene is required by CIAT899 for the ability to induce chlorosis in plants, we could not detect the expression of reporter genes transcriptionally fused to either $g \ln D$ or $m v i N$. Plasmids derived from pKO1 by mutagenesis with Tn3-HoKmGus (Fig. 1b) contained putative transcriptional fusions of $\beta$-glucuronidase to genes encoded on pKO1. Strain CT4812 carrying pKO1 with insertions in $g \ln D$ ( $\mathrm{pKO} 316$ ) or mviN (pKO370) that placed uidA under the control of a putative $g \ln D / m v i N$ promoter did not produce blue colonies on solid BSM medium containing X-gluc (data not shown). Strain ME370 (containing a uidA reporter in mviN located in the chromosome) also did not have detectable $\beta$-glucuronidase activity when grown on solid TY medium, or solid BSM minimal medium (10 g mannitol $\left.\mathrm{l}^{-1}\right)$ using proline, histidine, nitrate, or arginine $\left(1 \mathrm{~g} \mathrm{l}^{-1}\right)$ as sole nitrogen sources (data not shown). Therefore neither $m v i N$ nor $g \ln D$ was detectably expressed in minimal BSM, a medium that supports induction of chlorosis (O'Connell \& Handelsman, 1993). Therefore, either the level of expression of this gene in culture was below the limit of our detection, or some condition in the rhizosphere of chlorosis-susceptible plants stimulates the expression of $g \ln D$, and this condition was not present in our cultures.

We also examined the expression of several uidA fusions in pKO1 in CT4812 grown on TY medium (Fig. 1b) and observed results similar to those obtained using BSM. In a quantitative assay, CT4812 carrying pKO345, pKO316, or pKO370 also did not display detectable $\beta$ glucuronidase activity (data not shown). CT4812 carrying pKO302, with an insertion downstream of $m v i \mathrm{~N}$ in the region of the Shewanella gene sequence, produced dark-blue colonies on solid TY and BSM containing Xgluc (Fig. 1b; data not shown), suggesting that this gene is expressed in cells of CT4812 grown in TY or BSM medium.

None of the insertions in pKO1 eliminated the ability to restore chlorosis induction to CT4812 in repeated experiments, even though several of the transposon insertions mapped to $g \ln D$ (Fig. 1b). Since mutants CT4812 and ME245 (containing mutations in the genomic $g \ln D$ gene) do not induce chlorosis, the ability of plasmids carrying mutations in $g \ln D$ to restore chlorosis induction suggests that a wild-type copy of $g \ln D$ may have been reconstructed by recombination, since the strains are $\mathrm{Rec}^{+}$. Only a small minority of individuals in the rhizosphere population need to have experienced a marker rescue to see chlorosis in the host plant, because as few as $4 \times 10^{3}$ chlorosis-inducing bacteria cause symptoms in the presence of $9 \times 10^{8}$ non-
Table 3. Effect of a range of ratios of carbon: nitrogen on chlorosis induction by $R$. tropici strain CT9005

Chlorotic plants were rated on a scale of 1 (green leaves, no chlorosis) to 5 (nearly white leaves, severe or complete chlorosis). Each value represents the mean chlorosis rating of 8-10 plants \pm SE. CT9005 is a chlorosis-inducing derivative of CIAT899. Values followed by the same letter are not significantly different $(P<0.05)$ by Tukey's Studentized range test (HSD $=0.98)$. Mean chlorosis ratings are statistically comparable only within experiment.

\begin{tabular}{|lcc|}
\hline Mannitol (mM) & $\mathrm{NH}_{4} \mathrm{NO}_{3}(\mathrm{mM})$ & Chlorosis rating \\
\hline Expt 1 & & \\
54 & 84 & $1 \cdot 0 \pm 0 \cdot 0^{b}$ \\
54 & 18 & $1 \cdot 0 \pm 0 \cdot 0^{b}$ \\
54 & 0 & $4 \cdot 6 \pm 0 \cdot 2^{a}$ \\
Expt 2 & & \\
137 & 25 & $1 \cdot 1 \pm 0 \cdot 1^{b c}$ \\
137 & $12 \cdot 5$ & $1 \cdot 7 \pm 0 \cdot 2^{b c}$ \\
137 & $6 \cdot 25$ & $4 \cdot 5 \pm 0 \cdot 3^{a}$ \\
137 & $3 \cdot 1$ & $4 \cdot 0 \pm 0 \cdot 3^{a}$ \\
137 & $1 \cdot 6$ & $4 \cdot 4 \pm 0 \cdot 2^{a}$ \\
137 & 0 & $4 \cdot 4 \pm 0 \cdot 2^{a}$ \\
0 & 0 & $1 \cdot 0 \pm 0 \cdot 0^{c}$ \\
& & \\
\hline Mannitol (mM) & Glutamate $(\mathrm{mM})$ & Chlorosis rating \\
\hline Expt 3 & & \\
137 & & $1 \cdot 0 \pm 0 \cdot 0^{c}$ \\
137 & 150 & $1 \cdot 0 \pm 0 \cdot 0^{c}$ \\
137 & 75 & $2 \cdot 0 \pm 0 \cdot 4^{b}$ \\
137 & 37 & $4 \cdot 9 \pm 0 \cdot 1^{a}$ \\
137 & 19 & $4 \cdot 6 \pm 0 \cdot 2^{a}$ \\
0 & 9 & $1 \cdot 0 \pm 0 \cdot 0^{c}$ \\
\hline
\end{tabular}

inducers (K. P. O'Connell \& J. Handelsman, unpublished data).

\section{High nitrogen:carbon ratios in the rhizosphere prevent chlorosis induction}

The finding that a mutation in a homologue of $g \ln D$, a sensor of nitrogen status in enteric bacteria, prevented $R$. tropici strain CIAT899 from inducing chlorosis in bean plants, coupled with our earlier finding that chlorosis induction by type $B$ strains of $R$. tropici requires a carbon source added to the rhizosphere (O'Connell \& Handelsman, 1993) led us to determine whether the ratio of carbon and nitrogen sources in the rhizosphere affects chlorosis induction by CIAT899.

Nitrogen $\left(\mathrm{NH}_{4} \mathrm{NO}_{3}\right.$ or sodium glutamate) prevented chlorosis development completely when added with mannitol and bacteria at planting (Table 3 ). We tested the effect of several ratios of mannitol and nitrogen on the ability of CT9005 to induce chlorosis and found that increasing amounts of nitrogen decreased the severity of chlorosis induction. In a separate experiment, plants 
inoculated with cells of CT9005 suspended in $680 \mathrm{mM}$ $\left(125 \mathrm{~g} \mathrm{l}^{-1}\right)$ mannitol and $82 \mathrm{mM} \mathrm{NH} \mathrm{NO}_{3}$ developed chlorosis $(4 \cdot 9 \pm 0 \cdot 1, n=10)$, indicating that further increasing the amount of mannitol overcame the effect of added nitrogen. These data indicate that high nitrogen: carbon ratios in the rhizosphere, rather than simply the presence of fixed nitrogen, prevented chlorosis induction by $R$. tropici in bean plants. The effect of the higher $\mathrm{N}$ : $\mathrm{C}$ ratios on chlorosis induction was therefore identical to the effect of the mutation in the $g \ln D$ gene of CIAT899: both abolished chlorosis induction.

The addition of metal ions had little or no effect on the development of chlorosis in bean plants inoculated with $R$. tropici. The addition of $\mathrm{FeCl}_{3}(1.5 \mathrm{mM}), \mathrm{H}_{3} \mathrm{BO}_{3}$ (3.2 mM), NaFeEDTA $(0.8 \mathrm{mM})$ or $\mathrm{MgSO}_{4}(10 \mathrm{mM})$ to bacteria resuspended in $54 \mathrm{mM}$ mannitol did not reduce the severity of chlorosis induced by chlorosis-inducing strain CT9005 (data not shown). NaFeEDTA added at a higher concentration $(11 \mathrm{mM})$ reduced the severity of chlorosis. Inoculating plants with CT9005 in a $54 \mathrm{mM}$ mannitol/11 mM NaFeEDTA solution produced a mean chlorosis rating of $1 \cdot 9 \pm 0 \cdot 3$, versus $4 \cdot 6 \pm 0 \cdot 2$ for plants inoculated with CT9005 in mannitol alone $(n=$ $8-10$ plants per treatment, $P<0.05$ by Tukey's Studentized range test, HSD $=0 \cdot 91$ ). Plants treated with solutions containing mannitol plus glutamate, ammonium nitrate or metals without bacteria did not display any adverse or chlorotic symptoms (data not shown).

\section{DISCUSSION}

The goal of this study was to determine the basis for chlorosis induction in bean plants caused by $R$. tropici type $B$ strains. We were unable to isolate a cell-free fraction of $R$. tropici cultures with chlorosis-inducing activity (K. P. O'Connell \& J. Handelsman, unpublished data) and therefore used a genetic approach to dissect the phenomenon. We demonstrate here that a mutation in a homologue of the regulatory gene $g \ln D$ prevents $R$. tropici from inducing chlorosis in plants. The apparent lack of expression of this gene in culture media (including BSM minimal medium, which supports the chlorosis-inducing activity of the wild-type strain) provides an explanation for the absence of chlorosisinducing activity in culture filtrates of $R$. tropici and suggests that identifying a culture condition that facilitates the expression of $g \ln D$ may in turn lead to the production of a chlorosis-inducing activity that can be isolated from culture filtrates and identified. The apparent lack of expression of $g \ln D$ provides, in addition to the nutritional phenotypes of $g \ln D$ mutants described above, another contrast with the $g \ln D$ gene of $E$. coli, which is expressed constitutively (van Heeswijk et al., 1993). If the $g \ln D$ gene of $R$. tropici requires some condition or compound, or the lack thereof, in the plant rhizosphere for its expression, the inducing compound or condition must be widespread among dicotyledonous plants, since $R$. tropici can induce chlorosis in the leaves of sunflower, cucumber, tomato, alfalfa and berseem clover as well as common bean, but not wheat, corn, or bluegrass (O'Connell \& Handelsman, 1993).

The nitrogen-sensing role of $\mathrm{GlnD}$ proteins in enteric bacteria suggests that the product of the $\ln D$ homologue in $R$. tropici may function to regulate chlorosis induction in response to environmental nitrogen levels. The GlnD protein of E. coli is the first protein in a sensory/regulatory cascade (Kennedy et al., 1994; Merrick \& Edwards, 1995). Under conditions of limiting nitrogen, $\mathrm{G} \ln \mathrm{D}$ stimulates the expression of genes in the nitrogen regulon (ntrBC and genes under their control) and the derepression of nitrogen-assimilatory enzymes by uridylylating the next protein in the regulatory cascade, PII. Conversely, GlnD removes the uridylyl moiety from PII when nitrogen is plentiful. Mutations that eliminate $\mathrm{G} \ln D$ function therefore mimic perpetual nitrogen sufficiency, since PII is always in the unmodified state. Similarly, in this study a mutation in the $g \ln D$ gene of $R$. tropici strain CIAT899 mimicked the effect of high nitrogen:carbon ratios in the rhizosphere, conditions that also repressed the ability of CIAT899 to induce chlorosis in plants. It is therefore possible that $\mathrm{G} \operatorname{lnD}$ protein in CIAT899 ultimately regulates genes that lead to production of the chlorosis-inducing activity in response to the nitrogen: carbon ratio in the rhizosphere. However, we cannot formally eliminate the possibility that this protein is involved directly in the biosynthesis of a chlorosis-inducing factor, the synthesis of which is regulated by the environmental nitrogen : carbon ratio in an unknown manner.

Graf \& Ruby (1996) reported that Vibrio fischeri requires an intact homologue of $g \ln D$ in the colonization of the light-producing organ of the squid Euprymna scolopes. A glnD mutant of $V$. fischeri was isolated that is deficient in growth on a variety of nitrogen sources, deficient in siderophore production and does not maintain a symbiosis with the squid after the initial colonization. The involvement of $g \ln D$ in the production of the siderophore suggests a novel interaction in the regulation of genes that respond to environmental iron and genes of the nitrogen regulon. It is intriguing that the only compound other than nitrogen that significantly reduced the severity of chlorosis in plants contained iron, suggesting that a similar interaction between iron and nitrogen metabolism may occur in $R$. tropici. However, this result must be interpreted with caution, since high concentrations of iron (millimolar) were required to reduce the severity of chlorosis. The slight reduction in the severity of chlorosis caused by $11 \mathrm{mM}$ NaFeEDTA might also have been caused by the EDTA portion of the molecule, a possibility we have not yet fully tested.

The homologue of the $S$. typhimurium virulence gene $m v i N$ (also termed mviB in some reports) in R. tropici appears not to be required for chlorosis induction or for symbiotic nitrogen fixation. It is interesting to note that homologues of $m v i N$ are also present in E. coli, $H$. influenzae, C. trachomatis and M. tuberculosis, prokaryotes that are pathogenic to eukaryotes. A similar gene is also present in the cyanobacterium Synechocystis 
sp. strain 6803. The precise function of this gene is obscure in S. typhimurium, although deletions of mviN greatly reduce the virulence of $S$. typhimurium in mice (Carsiotis et al., 1989). mviN has no obvious function in $R$. tropici; however, its proximity to $g \ln D$ suggests that the two genes are co-transcribed and translationally coupled. The genomic environment for the $g \ln D$ gene of $R$. tropici is unlike that of $g \ln D$ in $E$. coli, where $g \ln D$ is flanked by the map and dap loci (van Heeswijk et al., 1992).

The nitrogen regulons of rhizobia and their role in symbiotic nitrogen fixation are not well characterized (Kennedy et al., 1994), relative to our understanding of nitrogen sensing in enteric bacteria (Merrick \& Edwards, 1995). No other homologues of $g \ln D$ have been reported from the rhizobia, although UTase/UR enzyme activities that respond to changing nitrogen levels have been observed in Rhizobium leguminosarum (Colanna-Romano et al., 1993). The PII protein from Rhizobium meliloti (Arcondéguy et al., 1997) has the conserved Tyr51 residue which receives the uridylyl group and can be uridylylated by $E$. coli, implying the presence of UTase/UR enzyme in R. meliloti. Whilst the inhibitory effects of nitrogen fertilizers on nodulation and nitrogen fixation by rhizobia are well known (Streeter, 1988), the genetics of nitrogen sensing, uptake and utilization in these important bacteria and the molecular interactions between nitrogen metabolism and symbiosis are only beginning to be understood. Further studies of the function of the $g \ln D$ homologue from $R$. tropici and other rhizobia will contribute to understanding these processes.

\section{ACKNOWLEDGEMENTS}

We thank Jocelyn Milner for providing the CIAT899 gene library. We thank an anonymous reviewer for suggesting a critical experiment. J. Milner, Michelle Rondon and an anonymous reviewer provided helpful comments on the manuscript. We are grateful to Gary Roberts for many valuable discussions. Joan Varner-Brown and Clara Scott provided technical assistance. This research was supported by Grant no. 89-37262-4746 from the Competitive Research Grants Office of the USDA, and by the University of Wisconsin-Madison College of Agricultural and Life Sciences project no. 3309.

\section{REFERENCES}

Arcondéguy, T., Huez, I., Tillard, P., Gangneux, C., de Billy, F., Gojon, A., Truchet, G. \& Kahn, D. (1997). The Rhizobium meliloti PII protein, which controls bacterial nitrogen metabolism, affects alfalfa nodule development. Genes Dev 11, 1194-1206.

Araujo, R. S., Maya-Flores, J., Barnes-McConnell, D., Yokoyama, C., Dazzo, F. B. \& Bliss, F. A. (1986). Semienclosed cultures of bean plants (Phaseolus vulgaris) for enumeration of Rhizobium phaseoli by the most-probable-number technique. Appl Environ Microbiol 52, 954-956.

Ausubel, F. M., Brent, R., Kingston, R. E., Moore, D. D., Seidman, J. G., Smith, J. A. \& Struhl, K. (editors) (1987). Current Protocols in Molecular Biology. New York: Wiley.

Beattie, G. A., Clayton, M. K. \& Handelsman, J. (1989). Quantitative comparison of the laboratory and field competitiveness of
Rhizobium leguminosarum bv. phaseoli. Appl Environ Microbiol 55, 2755-2761.

Bergersen, F. J. (1961). The growth of Rhizobium on synthetic medium. Aust J Biol Sci 14, 349-360.

Beringer, J. E. (1974). R-factor transfer in Rbizobium leguminosarum. J Gen Microbiol 84, 188-198.

Bliss, F. A., Pereira, R. S., Araujo, R. S., Henson, R. A., Kmiecik, K. A., McFerson, J. R., Teixeira, M. G. \& DeSilva, C. C. (1989). Registration of five high nitrogen fixing common bean germplasm lines. Crop Sci 29, 240-241.

Bloom, F. R., Levin, M. L., Foor, F. \& Tyler, B. (1978). Regulation of glutamine synthetase formation in Escherichia coli: characterization of mutants lacking the uridylyltransferase. $J$ Bacteriol 134, 569-577.

Bonas, U., Stall, R. E. \& Staskawicz, B. (1989). Genetic and structural characterization of the avirulence gene avrBs 3 from Xanthomonas campestris pv. vesicatoria. Mol Gen Genet 218, 127-136.

Brom, S., Martinez, E., Davila, G. \& Palacios, R. (1988). Narrowand broad-host-range symbiotic plasmids of Rhizobium spp. that nodulate Phaseolus vulgaris. Appl Environ Microbiol 54, 1280-1283.

Carsiotis, M., Stocker, B. A., Weinstein, D. L. \& O’Brien, A. D. (1989). A Salmonella typhimurium virulence gene linked to flg. Infect Immun 57, 3276-3280.

Colanna-Romano, S., Patriarca, E. J., Amar, M., Bernard, P., Manco, G., Lamberti, A., laccarino, M. \& Defez, R. (1993). Uridylylation of the PII protein in Rhizobium leguminosarum. FEBS Lett 330, 95-98.

Contreras, A., Drummond, M., Bali, A., Blanco, G., Garcia, E., Bush, G., Kennedy, C. \& Merrick, M. (1991). The product of the nitrogen fixation regulatory gene $n f r X$ of Azotobacter vinelandii is functionally and structurally homologous to the uridylyltransferase encoded by $g \ln D$ in enteric bacteria. J Bacteriol 173, 7741-7749.

Devereux, J., Haeberli, P. \& Smithies, O. (1984). A comprehensive set of sequence analysis programs for the VAX. Nucleic Acids Res 12, 387-395.

Ditta, G., Stanfield, S., Corbin, D. \& Helinski, D. R. (1980). Broad host range DNA cloning system for gram-negative bacteria: construction of a gene bank of Rhizobium meliloti. Proc Natl Acad Sci USA 77, 7347-7351.

Figurski, D. H. \& Helinski, D. R. (1979). Replication of an origincontaining derivative of plasmid RK2 is dependent on a plasmid function provided in trans. Proc Natl Acad Sci USA 76, 1648-1652.

Foor, F., Cedergren, R. J., Streicher, S. L., Rhee, S. G. \& Magasanik, B. (1978). Glutamine synthetase of Klebsiella aerogenes: properties of $g \ln D$ mutants lacking uridylyltransferase. J Bacteriol 134 , 562-568.

Geniaux, E., Flores, M., Palacios, R. \& Martinez, E. (1995). Presence of megaplasmids in Rhizobium tropici and further evidence of differences between the two $R$. tropici subtypes. Int J Syst Bacteriol 45, 392-394.

Graf, J. \& Ruby, E. (1996). Characterization of a Vibrio fischeri $g \ln D$ mutant: both iron and nitrogen utilization are affected. In Abstracts of the 96th General Meeting of the American Society for Microbiology 1996, p. 509, abstract H-149. Washington, DC: American Society for Microbiology.

Graham, P. H., Viteri, S. E., Mackie, F., Vargas, A. T. \& Palacios, R. (1982). Variation in acid soil tolerance among strains of Rhizobium phaseoli. Field Crop Res 5, 121-128. 
Hanahan, D. (1983). Studies on the transformation of Escherichia coli with plasmids. J Mol Biol 66, 557-580.

van Heeswijk, W., Kuppinger, O., Merrick, M. \& Kahn, D. (1992). Localization of the $g \ln D$ gene on a revised map of the 200kilobase region of the Escherichia coli chromosome. J Bacteriol 174, 1702-1703.

van Heeswijk, W. C., Rabenberg, M., Westerhoff, H. V. \& Kahn, D. (1993). The genes of the glutamine synthetase adenylylation cascade are not regulated by nitrogen in Escherichia coli. Mol Microbiol 9, 443-457.

Holm, L. \& Sander, C. (1995). DNA polymerase $\beta$ belongs to an ancient nucleotidyltransferase superfamily. Trends Biochem $\mathrm{Sci}$ 20, 345-347.

Jefferson, R. A. (1987). Assaying chimeric genes in plants: the GUS reporter gene fusion system. Plant Mol Biol Reporter 5, $387-405$

Kahn, M. \& Helinski, D. H. (1978). Construction of a novel plasmid-phage hybrid: use of the hybrid to demonstrate ColE1 DNA replication in vivo in the absence of a ColE1-specified protein. Proc Natl Acad Sci USA 75, 2200-2204.

Keen, N. T., Tamaki, S., Kobayashi, D. \& Trollinger, D. (1988). Improved broad-host-range plasmids for DNA cloning in gramnegative bacteria. Gene 70, 191-197.

Kennedy, C., Doetsch, N., Meletzus, D., Patriarca, E., Amar, M. \& laccarino, M. (1994). Ammonium sensing in nitrogen-fixing bacteria: functions of the $g \ln B$ and $g \ln D$ gene products. Plant Soil $161,43-57$.

Martinez-Romero, E., Segovia, L., Mercante, F. M., Franco, A. A. Graham, P. \& Pardo, M. A. (1991). Rhizobium tropici, a novel species nodulating Phaseolus vulgaris L. beans and Leucaena sp. trees. Int J Syst Bacteriol 41, 417-426.

Merrick, M. J. \& Edwards, R. A. (1995). Nitrogen control in bacteria. Microbiol Rev 59, 604-622.

Milner, J. L., Araujo, R. S. \& Handelsman, J. (1992). Molecular and symbiotic characterization of exopolysaccharide-deficient mutants of Rhizobium tropici strain CIAT899. Mol Microbiol 6, $3137-3147$.
O'Connell, K. P., Araujo, R. S. \& Handelsman, J. (1990). Exopolysaccharide-deficient mutants of Rhizobium sp. strain CIAT899 induce chlorosis in common bean (Phaseolus vulgaris). Mol Plant-Microbe Interact 3, 424-428.

O'Connell, K. P. \& Handelsman, J. (1993). Foliar chlorosis in symbiotic host and nonhost plants induced by Rhizobium tropici type B strains. Appl Environ Microbiol 59, 2184-2189.

Quandt, J. \& Hynes, M. F. (1993). Versatile suicide vectors which allow direct selection for gene replacement in gram-negative bacteria. Gene 127, 15-21.

Rosenberg, C. \& Huguet, T. (1984). The pATC53 plasmid of Agrobacterium tumefaciens is not essential for tumour induction. Mol Gen Genet 196, 533-536.

Sambrook, J., Fritsch, E. F. \& Maniatis, T. (1989). Molecular Cloning: a Laboratory Manual, 2nd edn. Cold Spring Harbor, NY: Cold Spring Harbor Laboratory.

Schwartz, H. F. (1991). Part II. Non-infectious diseases. In Compendium of Bean Diseases, pp. 59-62. Edited by R. Hall. St Paul, MN : APS Press.

Selveraj, G. \& lyer, V. N. (1983). Suicide plasmid vehicles for insertion mutagenesis in Rhizobium meliloti and related bacteria. J Bacteriol 156, 1292-1300.

Simon, R., Prieffer, U. \& Pühler, A. (1983). Vector plasmids for in vivo and in vitro manipulations of gram-negative bacteria. In Molecular Genetics of the Bacteria-Plant Interaction, pp. 98-106. Edited by A. Pühler. Heidelberg: Springer.

Stachel, S., An, G., Flores, C. \& Nester, E. W. (1985). A Tn3-lacZ transposon for the random generation of $\beta$-galactosidase gene fusions: application to the analysis of gene expression in Agrobacterium. EMBO J 4, 891-898.

Streeter, J. (1988). Inhibition of legume nodule formation and nitrogen fixation by nitrate. Crit Rev Plant Sci 7, 1-23.

Wacek, T. J. \& Brill, W. J. (1976). Simple, rapid assay for screening nitrogen-fixing ability in soybean. Crop Sci 16, 518-523.

Received 15 May 1998; accepted 26 May 1998 